\title{
DEVELOPING A SYSTEM FOR FISH FAUNA MIGRATION RESTORATION ABOVE THE SPILLWAY SILL NEAR THE CITY HALL OF ORADEA (ROMANIA)
}

\author{
Răzvan VOICU* and Liliana VOICU ** \\ * National Institute of Hydrology and Water management and Eco-Hydrology, Laboratory of Water \\ management and Eco-Hydrology, București-Ploiești Street 97, București, Romania, RO-013686, \\ rzvnvoicu@yahoo.com \\ ** National Institute of Hydrology and Water management and Eco-Hydrology, Laboratory of Water \\ management and Eco-Hydrology, București-Ploiești Street 97, București, Romania, RO-013686, \\ lilianavoicu80@gmail.com
}

DOI: 10.1515/trser-2015-0073

KEYWORDS: weir, system for fish migration, Crişul Repede River.

\section{ABSTRACT}

The channel of the river Crișul Repede inside the town affects both the biodiversity and implicit functionality of Crișul Repede River, therefore, this article aims to provide a solution for fish fauna migration in a system designed to restore longitudinal connectivity. The proposed migration system is based on the gravitational fall of water and will lead to the restoration of the longitudinal connection of Crişul Repede River near the weir selected as the study case. It will reconnect approximately three kilometers of habitat that will contribute to ensuring the optimal conditions for the development of migratory fish species present in the area.

RESUMEN: Desarrollo de un sistema para la migración de la fauna de peces por encima del travesaño vertedero cerca de la ciudad de Oradea.

El canalizado del río Crişul Repede dentro de la ciudad afectó la biodiversidad y la funcionalidad implícita del Rio Crişul Repede. Por lo tanto, este artículo tiene como objetivo proporcionar una solución para la migración de la fauna de peces, diseñada para restaurar la conectividad longitudinal. El sistema de migración propuesto se basa en la caída gravitacional del agua y dará lugar a la restauración de la conexión longitudinal del Río Crişul Repede cerca del vertedero seleccionado como caso de estudio. Se volverá a conectar un hábitat con una longitud de aproximadamente tres km que contribuirá para asegurar las condiciones óptimas para el desarrollo de especies de peces migratorias presentes en el área.

REZUMAT: Dezvoltarea unui sistem de restaurare a migrației faunei piscicole deasupra deversorului de lângă Primăria Oradea.

Canalul Crișului Repede în oraș afectează atât biodiversitatea, cât și funcționalitatea implicită a râului Crișul Repede. Prin urmare, acest articol își propune să ofere o soluție pentru migrarea faunei piscicole, un sistem conceput pentru a restabili conectivitatea longitudinală. Sistemul de migrare propus se bazează pe căderea gravitațională a apei și va conduce la restaurarea conexiunii longitudinale a râului Crișul Repede în apropierea pragului selectat, ca studiu de caz. Acesta va reconecta un habitat cu o lungime de aproximativ trei km, care va contribui la asigurarea condițiilor optime pentru dezvoltarea speciilor de pești migratori prezente în zonă. 


\section{INTRODUCTION}

There are many hydrotechnical facilities along the Crișul Repede River, including spillway sills. In the city of Oradea, there are sills located at the CFR Bridge, the City Hall of Oradea, the Dacia Bridge and many other locations. These spillway sills negatively affect the connectivity of the Crișul Repede River, strongly reducing its biodiversity and intrinsic ecological value. The need for longitudinal connectivity of rivers represents an essential condition of the Water Framework Directive approved by the European community and, therefore, should be applied to all streams containing migratory species. The subject of this case study proposes an ecotechnical solution consisting of frontal connectivity in the city of Oradea. The solution proposed for fish fauna migration upstream - downstream of the spillway sill situated at the City Hall of Oradea is practical, it can be developed without any expensive technology and does not affect the spillway sill structure and associated construction.

\section{RESULTS AND DISCUSSION}

\section{The fish fauna migration proposal}

To ease the migration of ichthyofauna above the spillway sill (Figs. 1 and 2), a system consisting of four winches with waterproof metal cables is developed using a rubbery, inelastic textured material with rhombic spacing connected to the cables of the winches. When it is raised, the material will hold the fish fauna (Fig. 3).

Around the edge of the textured material there will be a metal cable on which four symmetrical metal rings are welded (Fig. 3). Two metal or concrete pillars are affixed on both sides of the Crișul Repede River spillway sill (Fig. 4).

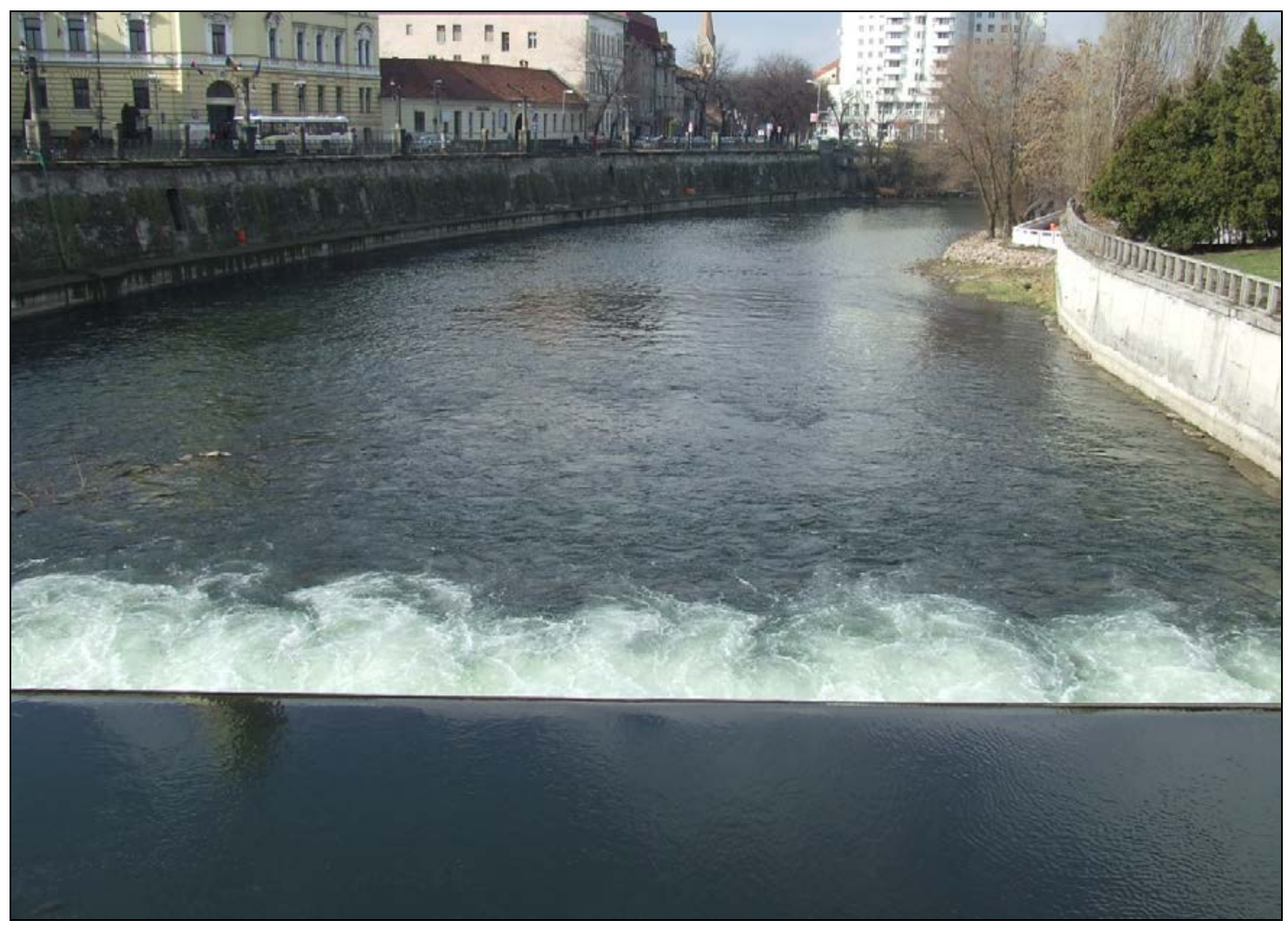

Figure 1: Spillway sill near the City Hall of Oradea. 


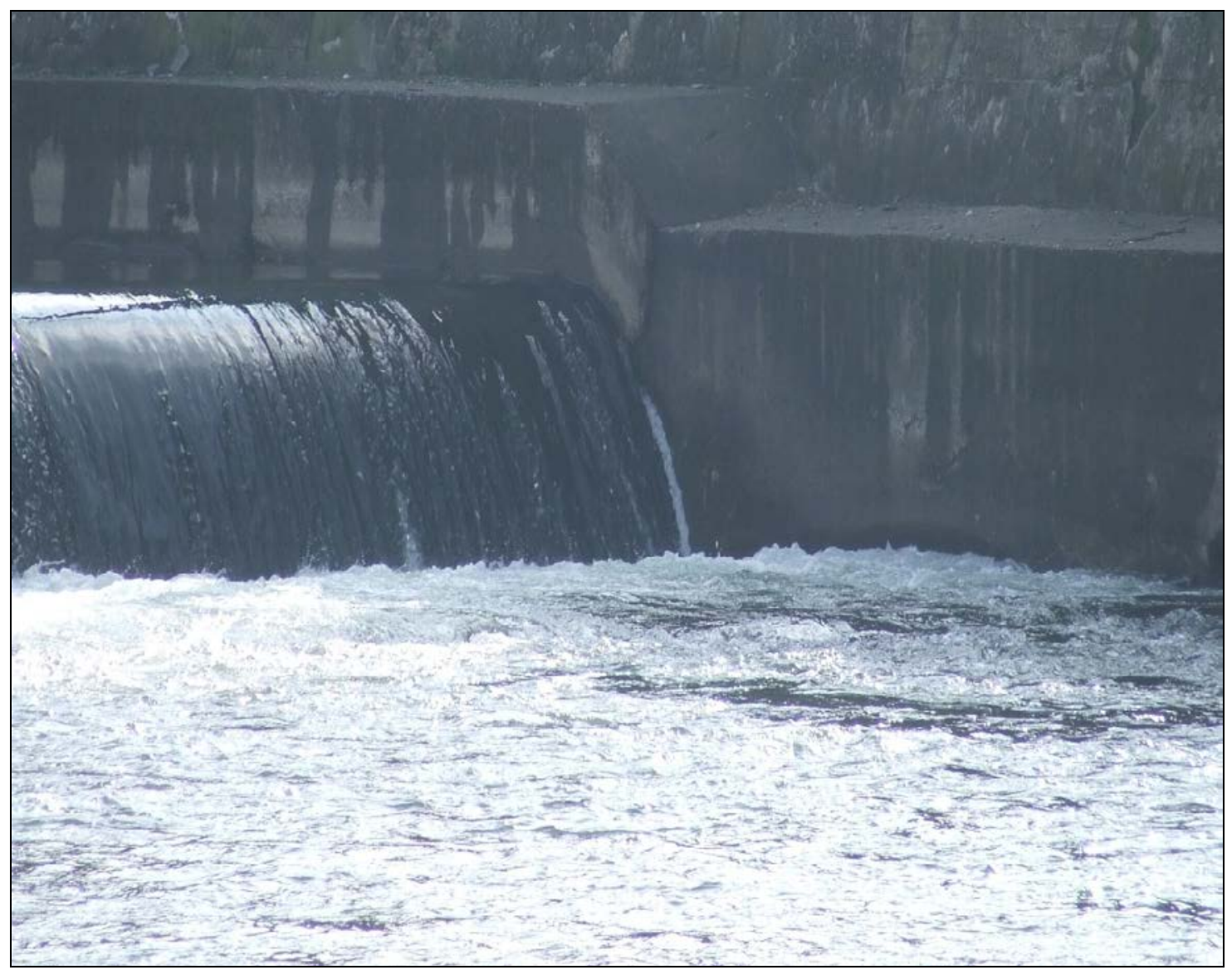

Figure 2: Spillway sill near the City Hall of Oradea.

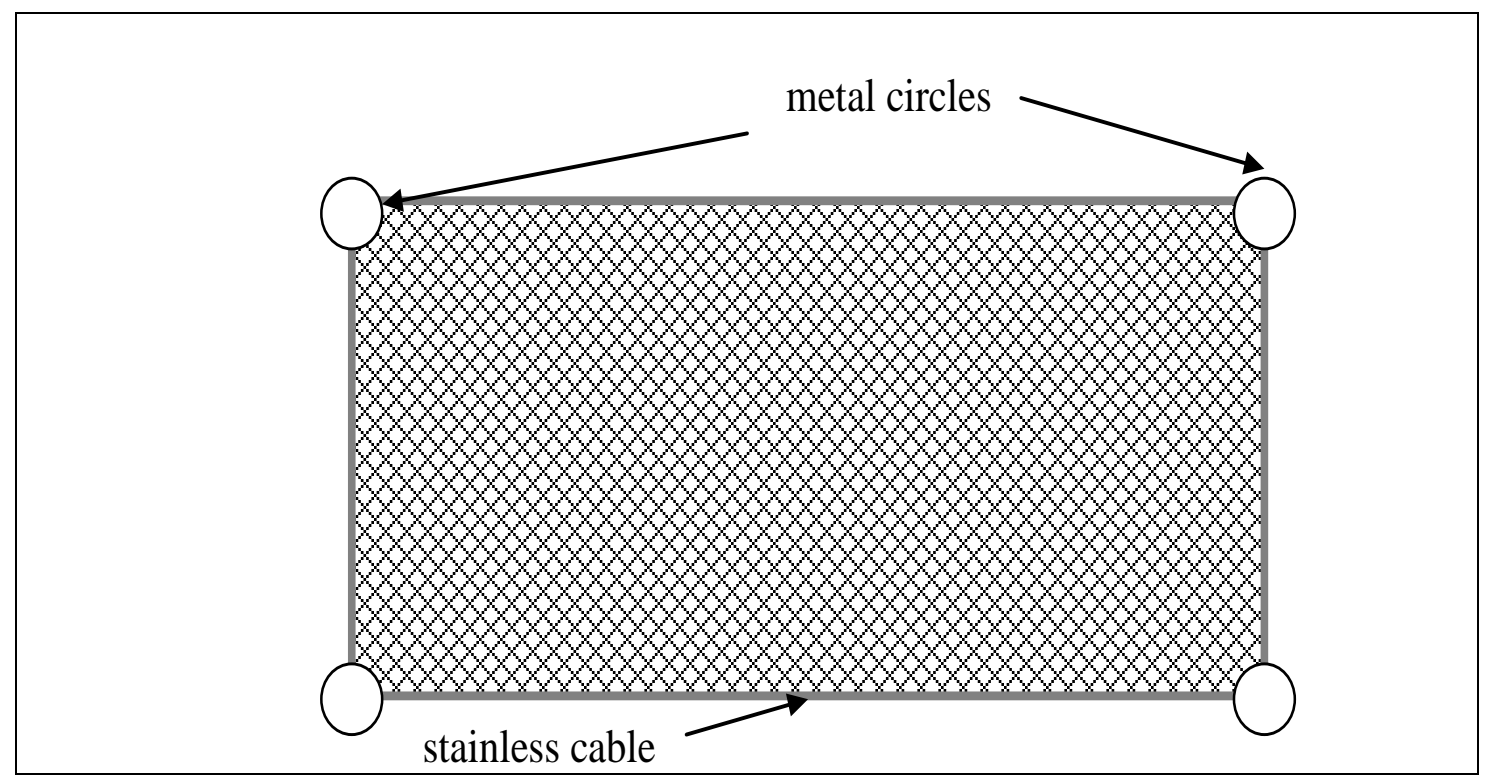

Figure 3: Schematic of system using rubbery inelastic texture with rhombic spacing. 


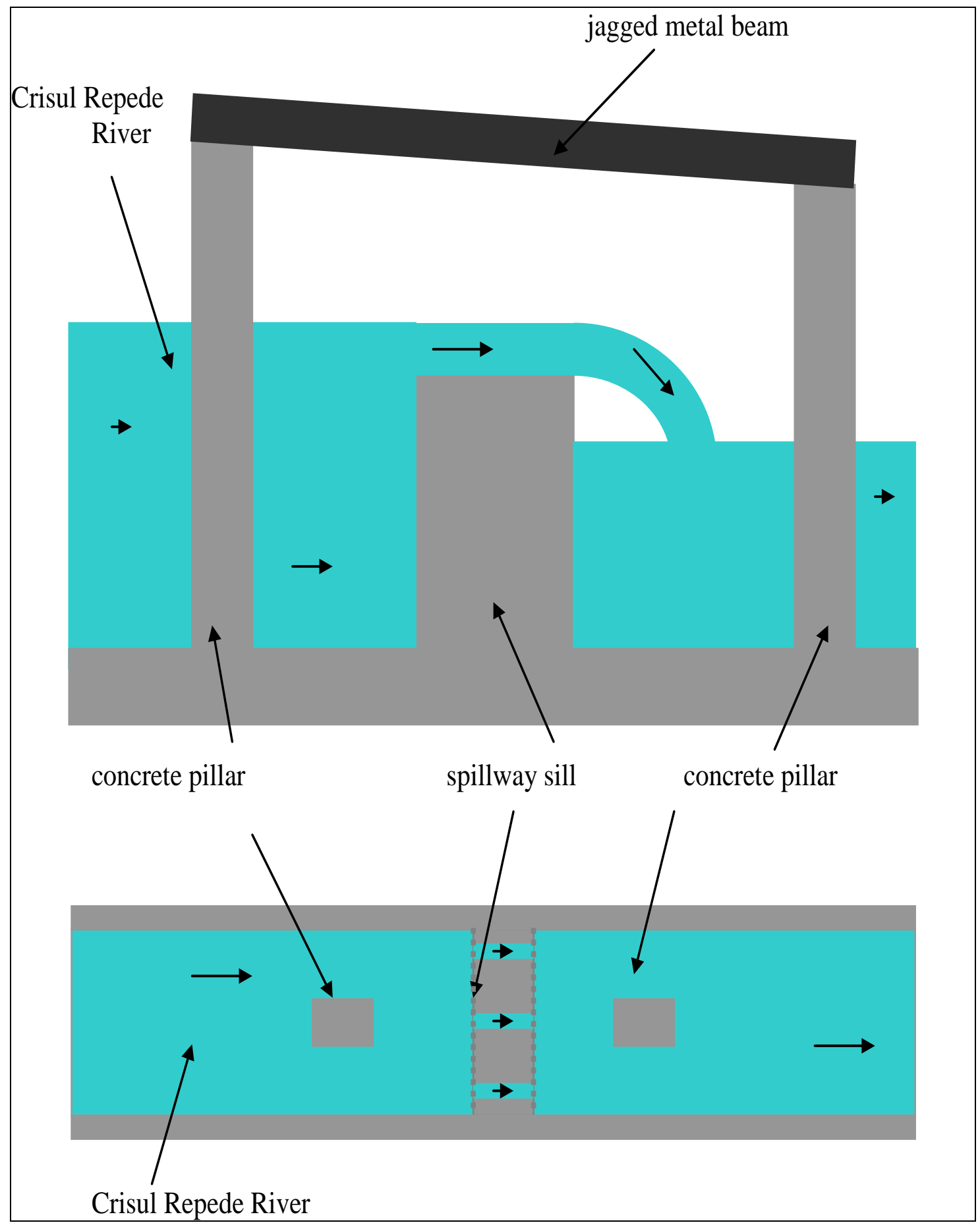

Figure 4: Schematic of positioning metal or concrete pillars.

A jagged metal beam is positioned on the two pillars on an inclined plane (Fig. 4). An electric rack-driven motor is attached to the upper side of the jagged metal beam (Fig. 5), and the metal rectangular housing of the electric motor is situated on the jagged metal beam using four bearings. 
electric motor

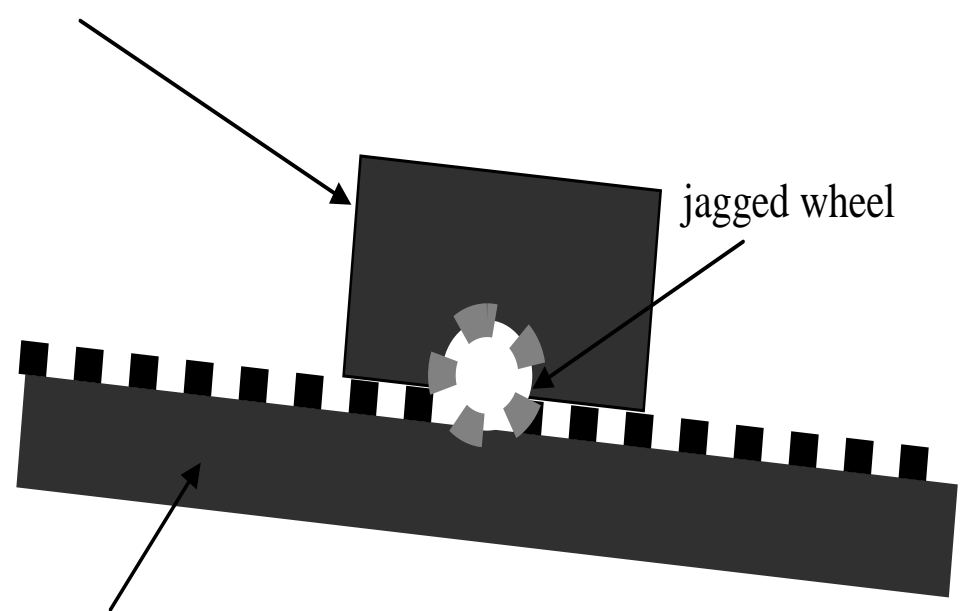

jagged metal beam

electric motor

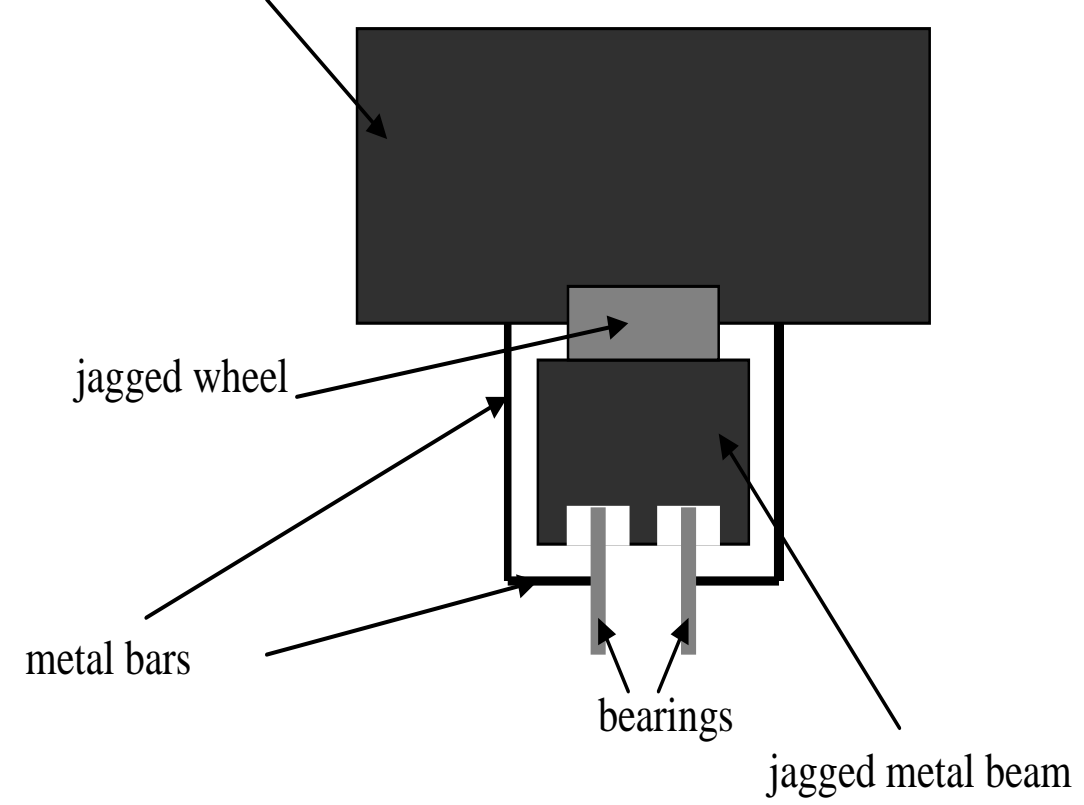

Figure 5: Schematic - Attaching the electric motor to the jagged metal beam.

The rack will spin moving the motor up and down on the jagged rail. Both upstream and downstream, the maximum distance at which the electric motor can come close to the two pilings is about one meter. Four winches like those used on SUVs are attached to the flat edges of the electric motor housing (Fig. 6). Also, on each edge of the motor housing, a spacer is welded a few inches below the winch. On the main bar each spacer is provided with a mobile 
cylinder to assist with the traction (Fig. 7). Spacers will help the winches and dragging cables to function so that the cables will not interfere with each other while raising the rubbery textured material (Fig. 8). The electric motor is supplied with electric power from the right bank of the river where the local electricity supply is located (Fig. 9).

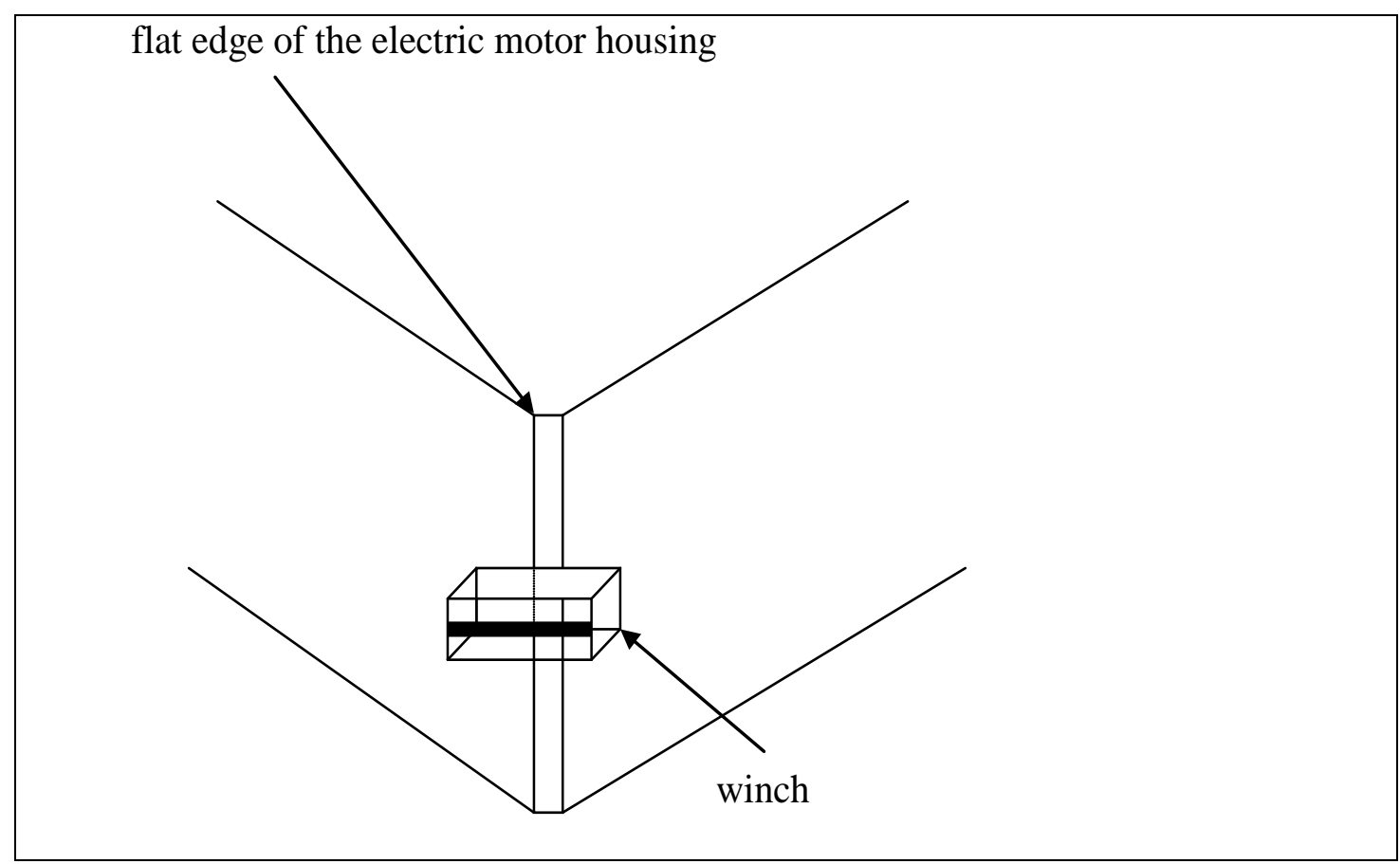

Figure 6: Schematic - Positioning of the winch on the electric motor.

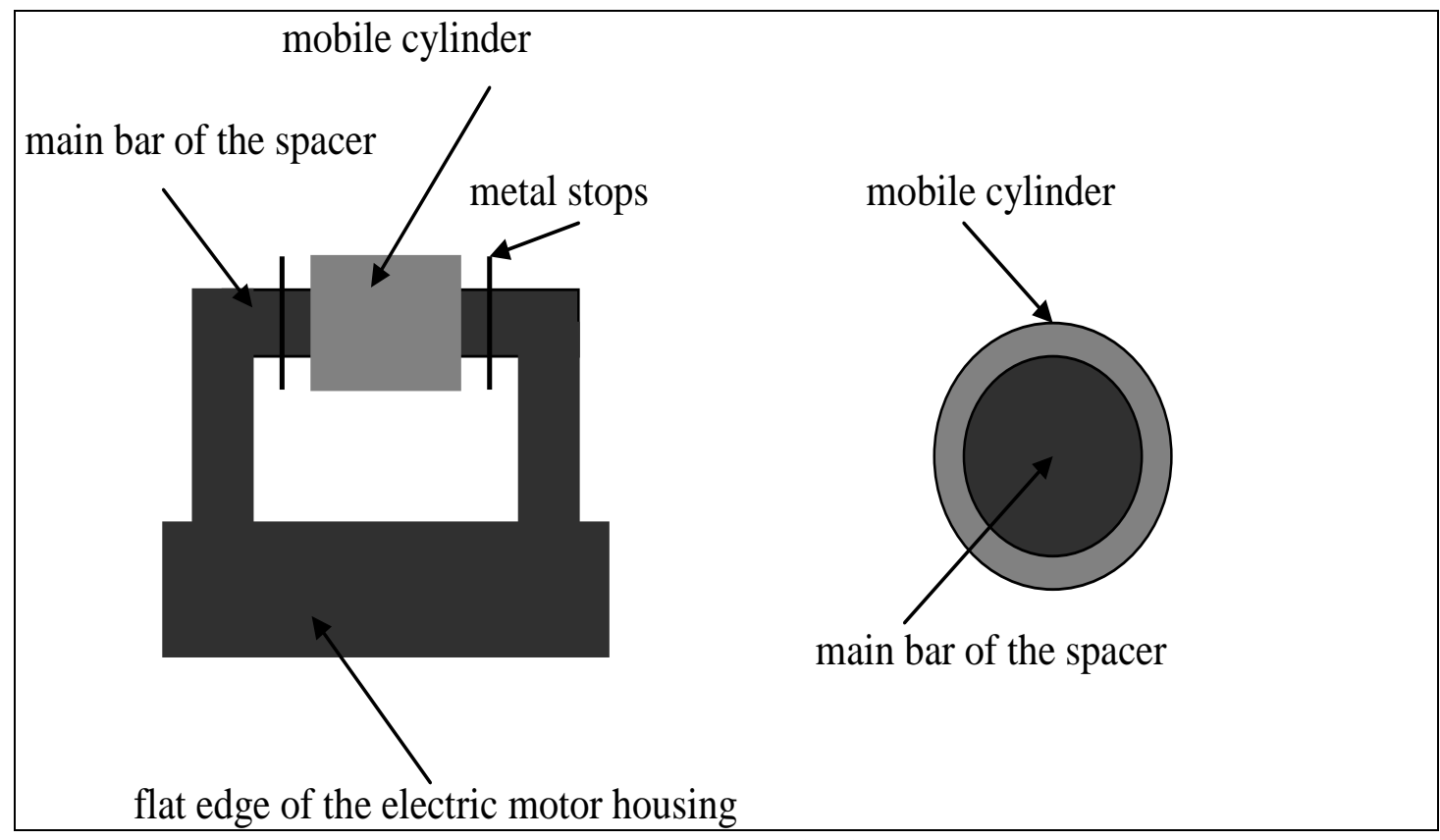

Figure 7: Schematic - Positioning the spacer. 


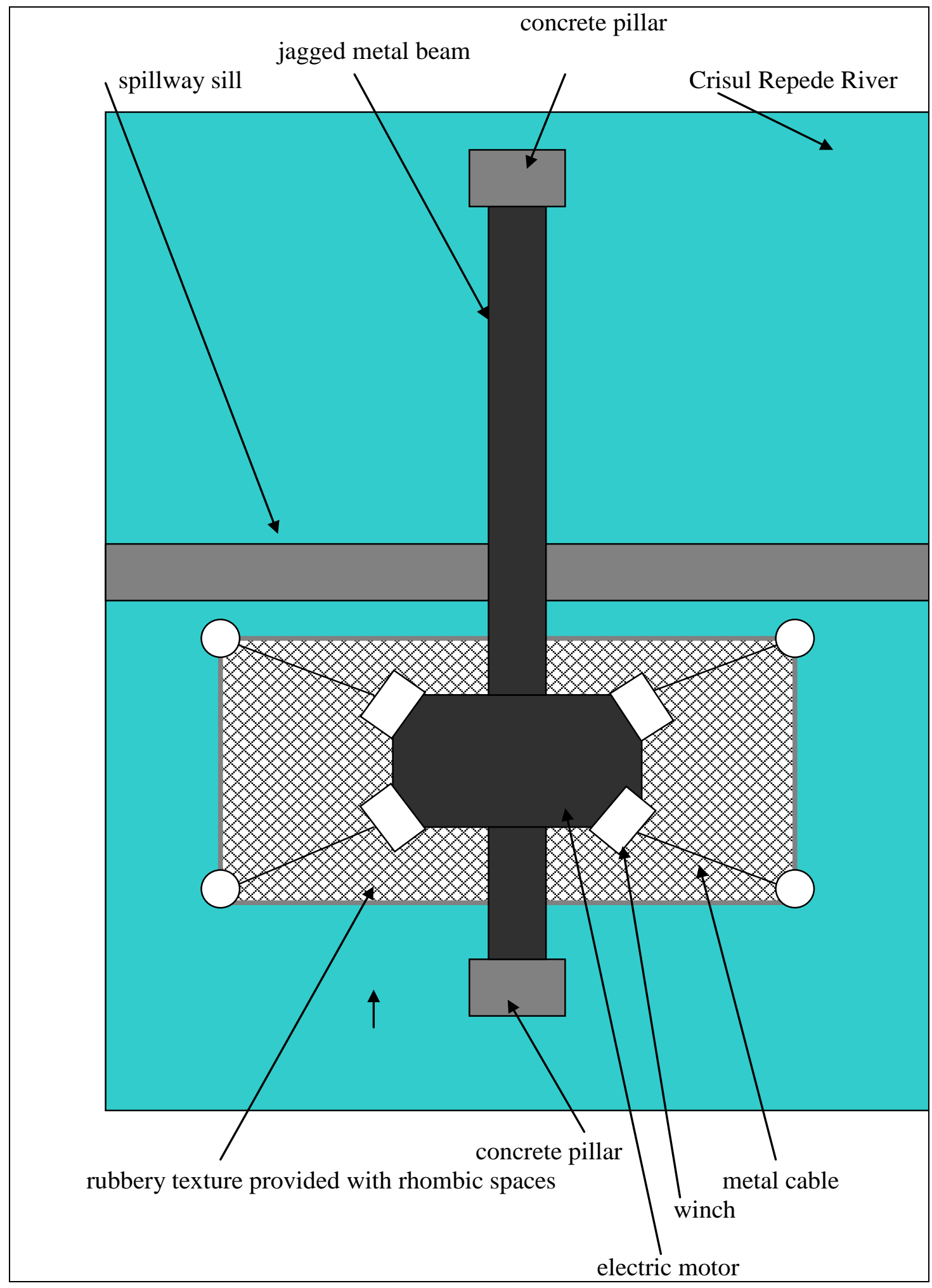

Figure 8: Schematic - Positioning the electric motor. 


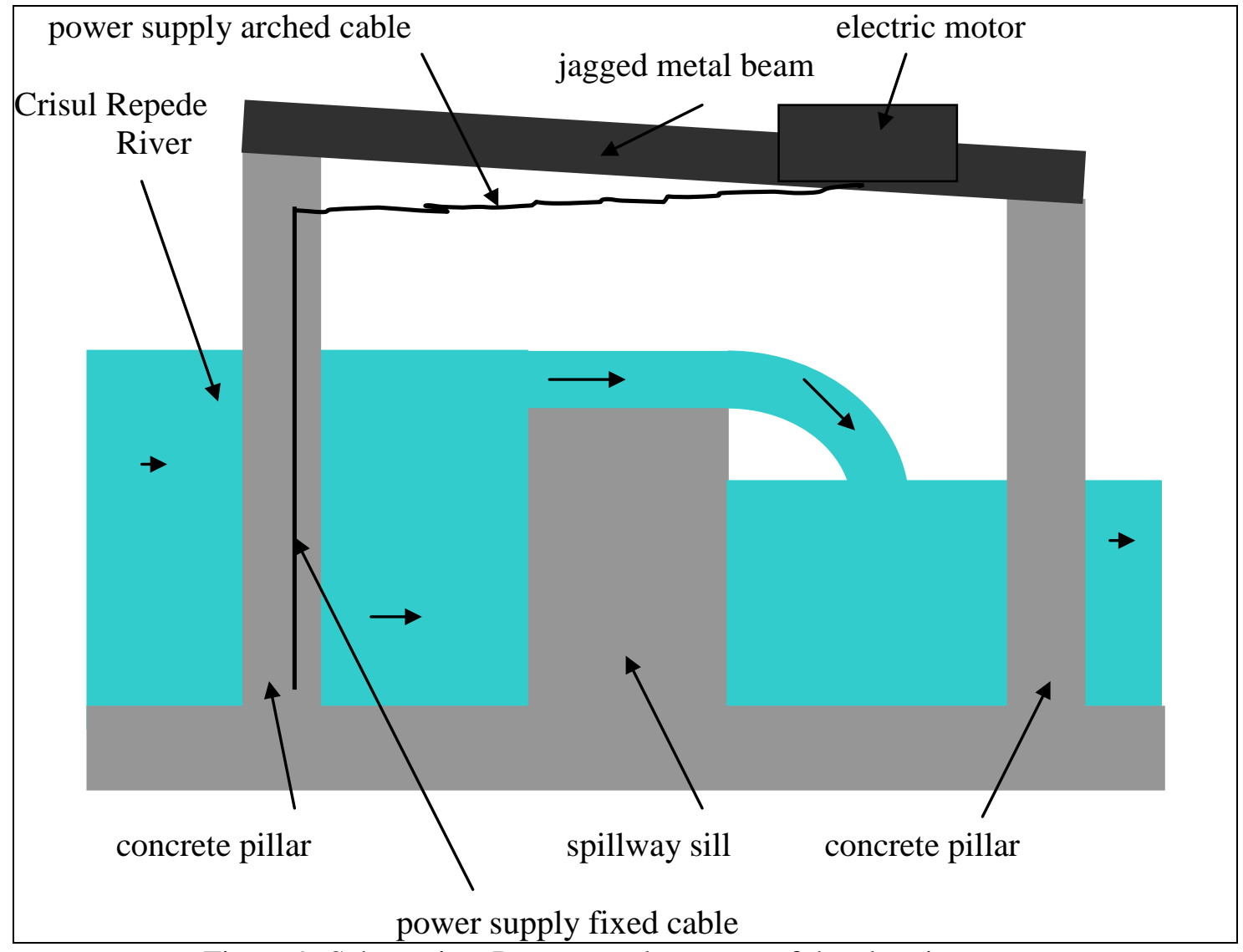

Figure 9: Schematic - Power supply system of the electric motor.

The motor will be attached by a fixed cable near the jagged bar. The fixed cable then turns into an arched cable that can be extended up to the spillway sill. Surveillance cameras will be installed on both banks of the river in order to observe various species of fish gathering together near the sill at the rubbery texture. The electric motor and the winches are connected to a computer to allow for them to be activated from tens of kilometres away using informational software. For migratory fish species to reach the rubbery texture, some electromagnetic field systems will be set using floating generators obliquely positioned on the spillway sill (Fig. 10). The advantages of this solution are; the possibility of application in almost any area of the world, an average execution cost, low maintenance costs and, in the case of invalidity, the technology already installed can be transferred to another spillway sill in another area. 


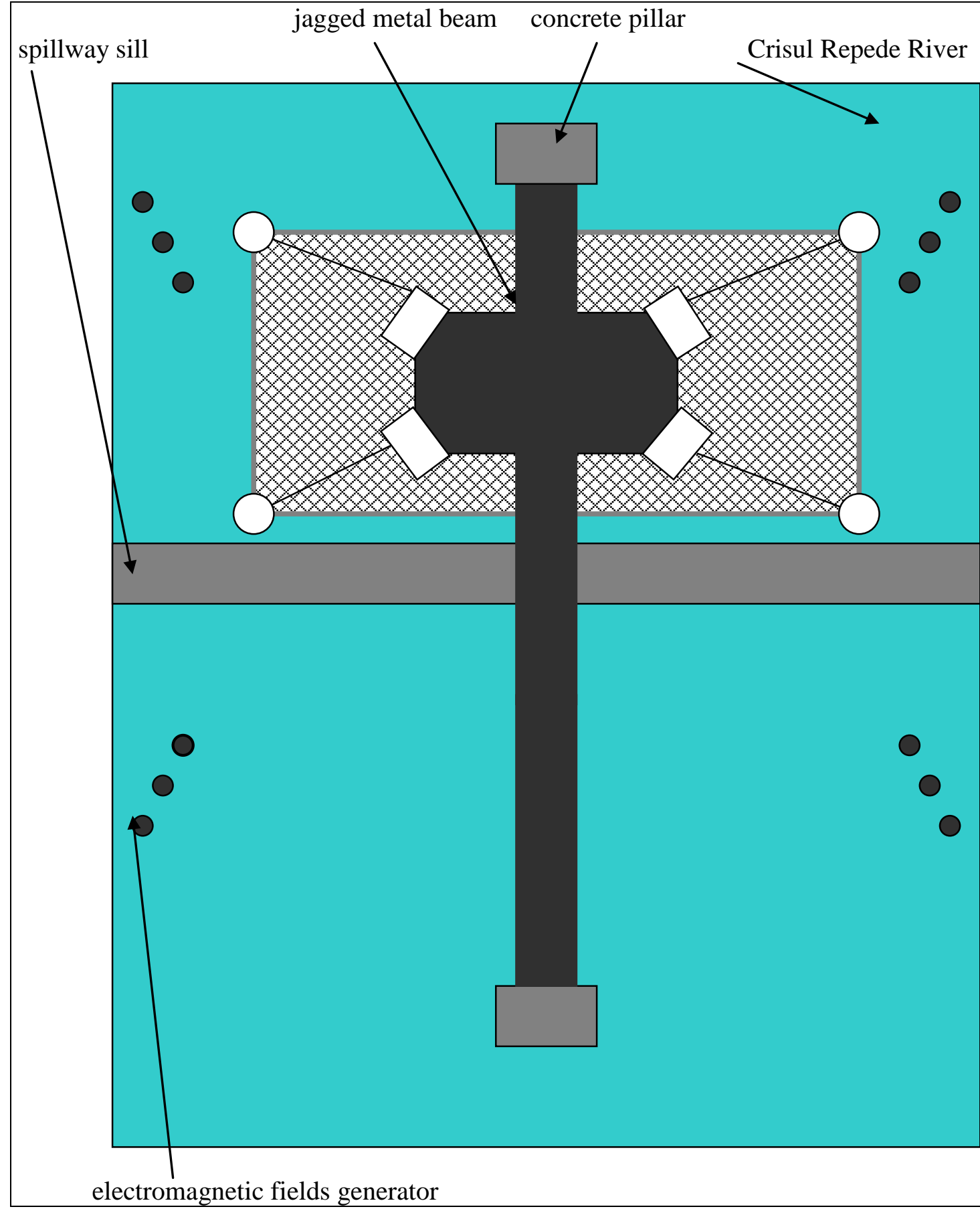

Figure 10: Schematic - Positioning the electromagnetic field generators. 


\section{CONCLUSIONS}

This specific system of fish migration upstream-downstream of the spillway sill provides longitudinal connectivity of the Crișul Repede River and represents a major benefit to the local lotic ecosystem restoration. The technical solution proposed here is practical, can be developed without any expensive technology, and does not affect the spillway sill structure and associated construction. Ichtyofauna modality transfer upstream - downstream of the weir is done considering all safety issues and avoids stresses largely above the spillway passage for fish. This system can be used in all existing discharge sills in the city of Oradea.

\section{SELECTIVE REFERENCES}

1. Bănărescu P., 1964 - Fauna of P. R. R. Academy edition, Bucharest, 958. (in Romanian)

2. Bănărescu M. P. and Bănăduc D., 2007 - Habitats Directive (92/43/EEC) fish species (Osteichthyes) on the Romanian Territory, Acta Ichtiologica Romanica, II, 43-78.

3. Diaconu S., 1999 - Cursuri de apă. Amenajare, impact, reabilitare, Edit. ${ }^{*} H^{*} G^{*} A$, Bucureşti. (in Romanian) 